\title{
Construction of Modern Information Technology Training base Centered on E-commerce Innovation and Entrepreneurship
}

\author{
Xuegang Zhang ${ }^{1, a}$ and Shaojie Xie ${ }^{1, b^{*}}$ \\ ${ }^{1}$ Guangdong food and drug vocational college, GuangZhou, China \\ azhangxg@gdyzy.edu.cn, ${ }^{b} x i e s j @ g d y z y . e d u . c n$
}

Keywords: E-commerce; Innovation and entrepreneurship; Quality training; Base construction

\begin{abstract}
With the start of the slogan of innovation and entrepreneurship, innovation and entrepreneurship have become the key development direction. Based on the theme of "innovation and entrepreneurship" on the hot topic of current vocational education, this paper discusses the construction of modern information technology practice base with the core of e-commerce innovation and entrepreneurship. Following the development ideas of "serving as the purpose, employment oriented, and combining production and learning", starting from the construction of "mass entrepreneurship and innovation" in schools, the existing training rooms are perfected and upgraded, and the reform efforts are strengthened to continuously expand and improve the practical teaching conditions, so as to meet the needs of the practical teaching in the school. In order to further strengthen the cooperation between schools and enterprises and to promote the combination of work and learning, we should build an e-commerce innovation and entrepreneurship training center to highlight the practice of teaching and the cultivation of entrepreneurial and innovative talents.
\end{abstract}

\section{Introduction}

In recent years, with the rapid development of Internet, the number of Internet users in China has been growing at an amazing speed every year. E-commerce has developed rapidly in China. The network shopping has made rapid development, and the volume of transactions is high, and it has gradually become a fashion in today's society. With the rapid development of "mass entrepreneurship and innovation" strategy, innovation and entrepreneurship is to enhance the ability of school intelligence and talent support, deepen vocational education integration, school enterprise cooperation, play the joint role of school enterprise joint operation, speed up the construction of modern vocational education system, and comprehensively enhance the service economy and social development ability. This paper, through the construction of e-commerce "mass entrepreneurship and innovation", while meeting the e-commerce operating skills of students, entrepreneurship and innovation ability enhancement needs and socialized training needs, comprehensively improve the quality of talent, improve the level of social services, promote innovation in personnel training, lead the development of local vocational education, make colleges and universities e-commerce develop faster and better.

\section{The Innovation and Entrepreneurship Education Mode of E-Commerce Specialty Under the Background of "Internet Plus"}

For e-commerce students in the "Internet plus" era, they should fully grasp and use the knowledge of innovation and entrepreneurship so that they can change "passivity" into "initiative" in the competition for employment in the social market, and enhance their ability to compete for employment. Under the background of "Internet plus", the training objectives and subject settings of e-commerce innovation and entrepreneurship are as follows.

The cultivation goal of "Internet plus" mode

As both the two-way talents resource of e-commerce and Internet, the students of e-commerce specialty are not only the abundant professional knowledge reserve, but also make them accept the curriculum knowledge of innovation and entrepreneurship, have the ability of innovation and 
entrepreneurship, transform knowledge into practice, and become the main force of innovation and entrepreneurship after graduation. Therefore, the teaching idea of e-commerce specialty education should be integrated into "Internet plus" innovation and entrepreneurship mode. The design of e-commerce talents training and education scheme can focus on the innovation spirit of "Internet plus", which makes the talents training of electronic commerce majors highlight the advantages of "Internet plus" under the pattern of "innovation and entrepreneurship".

The reasonable setting of the course of "Internet plus" innovation and entrepreneurship

In order to train more innovative and entrepreneurial talents, it is necessary to pay more attention to the innovative and entrepreneurship course in the course setting for the students majoring in e-commerce in colleges and universities. By combining the innovative and entrepreneurial knowledge of the Internet with the professional knowledge learned by the students, the innovative and entrepreneurial thinking of the students can be inspired. Specifically, on the basis of the previous courses on innovation and entrepreneurship, and by merging with the major courses in e-commerce, we have set up courses that include the "Internet plus" type of entrepreneurship. Make students learn professional knowledge and innovative knowledge of effective integration.

\section{On the current situation and problems of e-commerce specialty education of innovation and entrepreneurship}

Up to now, although e-commerce majors have many advantages and attract many students to enter for such majors every year, there are still some problems to be solved in college education. For example, there are many problems in the orientation of the students talent training goal, the design of the scheme, the formulation of the relevant professional courses, the teaching methods of the teachers and the guarantee system for the students of the major.

The orientation of innovation and entrepreneurship in the goal of talent training is not clear.

E-commerce is a multi-disciplinary, multi-angle subject, whose contents include computer technology, marketing, economics, management and other related professional knowledge. Can be seen as a combination of computer technology and marketing knowledge, and for the weight of the two, different schools have different emphasis. Many colleges and universities often ignore the important role of innovation and entrepreneurship in the development of personnel training goals for e-commerce students, which has produced a lot of negative results.

There is a lack of courses to teach innovation and entrepreneurship.

Through the understanding of the course of e-commerce major in colleges and universities, it is found that the major is mixed with multidisciplinary knowledge. Many colleges and universities have put information technology, marketing, management and economics to a certain proportion in a certain proportion, for students to learn, and do not form a mature teaching system. The innovation and entrepreneurship education course is a course that is not generally opened in college education. Some universities only set the innovation and entrepreneurship education as a public course, while some universities only introduce them as knowledge content to students in the form of lectures. The final result of this phenomenon is that innovation and entrepreneurship education has not been paid enough attention to students, so that most students do not really grasp the knowledge and skills of innovation and entrepreneurship.

The strength of innovative and entrepreneurial teachers is weak.

In the process of imparting knowledge about the innovation and entrepreneurship curriculum, it is extremely important for teachers to master the level of knowledge and impart knowledge. But in reality, because the e-commerce specialty is a new type of specialty, its appearance as a college education specialty does not last long. As a result, many teachers who teach in e-commerce professional courses do not come from the branch, but from other related professions to the profession. Under this circumstance, many university teachers directly enter the teaching of this course after graduation, and have not really participated in the innovation and entrepreneurship research of e-commerce in social practice. In the entire classroom teaching, they can only learn while teaching, and they lack practice. The practical experience is not conducive to students' ability to cultivate their innovative practice. 


\section{The significance of the construction of innovation and entrepreneurship base with e-commerce as the core under the background of "Internet plus"}

The need to cultivate innovative and skilled talents in e-commerce.

It is the fundamental task of vocational education to train the high quality workers and practical technical personnel in the front line of production and service with the aim of service and employment oriented. In order to cultivate technical and applied talents with innovative and entrepreneurial consciousness, strong practical ability and professional ability, we must strengthen the consciousness of innovation and entrepreneurship, and stress the independent position of students in the teaching process. The initiative of students in learning is driven by innovation and entrepreneurship. It is very necessary and urgent to build an e-commerce innovation and entrepreneurship practice base. With such a training base, students can practice innovation and entrepreneurship in a completely professional environment, and then they can train their own skills, lay a good foundation for employment.

Plays an important role in the outsourcing of e-commerce services.

The outsourcing of e-commerce service is an inevitable trend. At present, Alibaba and other famous e-commerce companies outsource some of the business services of some e-business services, and it is important that many small and medium-sized enterprises in our province generally recognize the necessity of developing electronic commerce. But because of the lack of funds, professionals and other factors, they have also used the way of outsourcing services to realize e-commerce. Therefore, through the practice of e-commerce service outsourcing, a group of talents who are good at outsourcing of e-commerce services can play a certain role in promoting the outsourcing of e-commerce service in our province.

The needs of the construction of the major group.

The practice of innovation and entrepreneurship in e-commerce involves the combination of multidisciplinary knowledge in the field of computer and business, which objectively requires the development of e-commerce major to develop other related specialties at the same time. At present, it has formed a multi-disciplinary group, which is based on the specialty of e-commerce, with the support of computer network technology, digital media technology, network editing technology and other specialties. The construction of the professional group has maintained and strengthened the specialty and brand advantage of e-commerce, which is beneficial to the formation of practical teaching advantages, teachers' joint force, lower cost of training construction and the improvement of teaching quality.

\section{Construction and implementation of innovation and entrepreneurship base for e-commerce under the background of "Internet plus"}

Basic skills training room

Focusing on strengthening basic and general technical skills training, we will strengthen the construction of basic teaching-type skills and practical training facilities, strengthen post professional skills, and meet e-commerce basic skills, electronic products, physical operations and distribution, and business negotiation training needs, enhance the school's basic practical teaching ability.

Off-campus e-commerce training room

Taking the Chaoyang city e-commerce park as the carrier and taking the cooperation of school and enterprise as the precondition, focusing on the construction of vocational and employment ability, we should build an off-campus e-commerce training platform, highlight the characteristics of modular training, promote the integration and sharing of vocational skills training resources, and create e-commerce operational skills, Internet marketing, mobile e-commerce, cross-border e-commerce and other training bases to enhance the school social service capacity.

Innovation and entrepreneurship training room

Innovation and entrepreneurship training room adheres to government guidance and market guidance, deeply implements the guiding ideology of "mass innovation and entrepreneurship ", and 
actively complies with the development trend of "open innovation, collaborative innovation, and mass innovation". According to the Internet and its applications to develop and innovate the needs of the development of entrepreneurship, we can effectively use the social strength and the advantages of existing resources to achieve professional docking, enterprise docking, enterprise capital docking, and enterprise information docking functions. For school e-commerce students, social personnel, e-commerce professional teachers and entrepreneurs to provide good entrepreneurial space, project incubation space and project operation space, to improve the students' social adaptability and entrepreneurial ability.

E-commerce innovation and entrepreneurship center

Build a one-stop e-commerce innovation and entrepreneurship center based on basic skills training room, off-campus e-commerce training room, and innovation and entrepreneurship training room, combining the existing school environment with local specialty products, integrating business operations and practical experience. Provide students and social workers with a one-stop innovation and entrepreneurship platform to enable students and social workers to understand e-commerce online and offline operations, and use mainstream information technologies such as Weibo and Wechat to experience online and offline purchases. Provide students with internship practice opportunities, through the formal operation of regional specialty products, create business opportunities, attract all sectors of society to participate in, promote the development of local tourism, achieve a win-win situation of organic unity and continuous service of teaching goals and commercial goals, the service of regional development and industrial revitalization will be directly provided, and the students' ability of innovation and entrepreneurship is enhanced.

\section{Summary}

According to the needs of the regional e-commerce industry and the development of schools, further change the educational ideas, update the educational concept, and actively adapt to the requirements of the state and government for the e-commerce talents, give full play to the advantages of regional economy and school resources, and integrate the power of e-commerce, such as industry, education, scientific research and so on, to integrate resources from all sides. Building an e-commerce training room outside the campus and innovative entrepreneurship training room to build a one-stop e-commerce innovation and entrepreneurship center, through the integrated line of online resources to provide more quality and convenient services for the entrepreneurs, the real operation platform around the WeChat public, integrated mobile e-commerce, to carry out real project operation. Finally, the goal of improving the professional level and management level, improving the quality of professional training, setting up the innovation and entrepreneurship center with industry, reasonable structure and distinctive features, mass innovation and entrepreneurship.

\section{Acknowledgements}

The authors and their work were Supported by:

Natural Science Fund Project of Guangdong Food and Drug Vocational College , grant no.: $2017 Z R 025$.

Guangdong Society of Vocational and Technical Education(2015 general), grant no.: GDGZ15Y049.

Education Research Fund Project of Guangdong Food and Drug Vocational College , grant no.: 2018JG02.

Innovation and Entrepreneurship Training Project of Guangdong Food and Drug Vocational College, grant no.: 2018DC02.

\section{References}

[1] Onetti A, Zucchella A, Jones M V, et al. Internationalization, innovation and entrepreneurship: business models for new technology-based firms[J]. Journal of Management \& Governance, 
2012, 16(3):337-368.

[2] Ellis T. The New Pioneers: Sustainable business success through social innovation and social entrepreneurship[J]. International Small Business Journal, 2010(1):3.

[3] Soriano D R, Huarng K H. Innovation and entrepreneurship in knowledge industries[J]. Journal of Business Research, 2013, 66(10):1964-1969.

[4] Carayannis E G, Campbell D F. Editorial preface to the first volume of Journal of Innovation and Entrepreneurship[J]. Journal of Innovation \& Entrepreneurship, 2012, 1(1):1.

[5] Sahut J M, Peris-Ortiz M. Small business, innovation, and entrepreneurship[J]. Small Business Economics, 2014, 42(4):663-668.

[6] Huggins R, Thompson P. Entrepreneurship, innovation and regional growth: a network theory[J]. Small Business Economics, 2015, 45(1):103-128.

[7] Edwards-Schachter M, García-Granero A, Sánchez-Barrioluengo M, et al. Disentangling competences: Interrelationships on creativity, innovation and entrepreneurship[J]. Thinking Skills \& Creativity, 2015, 16:27-39.

[8] Tian M, Zhang Y, Tang Z, et al. Study on the Patterns of Innovation \& Entrepreneurship Development and Enlightenment for China[J]. Science of Science \& Management of S \& T, 2016.

[9] Gao J W, Business D O. Building Marketing System Based on Creativity,Innovation and Entrepreneurship:A Case Study of the Business Plan of "Health-rooms"[J]. Journal of Huaihai Institute of Technology, 2015.

[10] Kazemi M, Pour S. Exploring effect of entrepreneurship and business orientations on innovation and customer value (Case Study: food industry of Mashhad city)[J]. New Marketing Research Journal, 2012, 2(2):1618-1623.

[11] Zhang Z, Li X. Performance Appraisal and Research on Policy of Innovation and Entrepreneurship Based on the DEA Model— Take Tianjin Business Incubators as the Analysis Objects[J]. Journal of Tianjin University, 2016.

[12] Galindo M Á, Méndez M T. Entrepreneurship, economic growth, and innovation: Are feedback effects at work? $₹[\mathrm{~J}]$. Journal of Business Research, 2014, 67(5):825-829.

[13] Provasnek A K, Schmid E, Geissler B, et al. Sustainable Corporate Entrepreneurship: Performance and Strategies Toward Innovation[J]. Business Strategy \& the Environment, 2017.

[14] Schmitz A, Urbano D, Dandolini G A, et al. Innovation and entrepreneurship in the academic setting: a systematic literature review[J]. International Entrepreneurship \& Management Journal, 2017, 13(2):1-27. 